\title{
The motivational peculiarities of bribe-takers
}

\author{
A. Krivins \\ Daugavpils University, Daugavpils, Latvia
}

\begin{abstract}
Criminology (as the scientific study of criminal behaviour on the individual and social level) and psychology (as the science, which seeks to understand individuals and groups) pay special attention to motivation - a theoretical construction, used to explain behaviour. In this article, the motivation of recipients of bribery is widely investigated. In addition to such well-established motives as greediness, selfishness, prevalence of personal interest, the author analyses also other criminal behaviour determinants. The works, which are used in this research are of the following authors: John Broadus Watson, Edward Lee Thorndike (Behavioural); Sigmund Freud, Erich Fromm (Psychoanalysis); Carl Rogers, Abraham Maslow (Existential-humanistic theories); William Isaac Thomas (Thomas theorem); Florian Witold Znaniecki (sociological theory); Erik Homburger Erikson (theory on psychosocial development of human beings); Jean William Fritz Piaget (theory of cognitive development); Herbert Lefcourt, Ronald Smith (Locus of Control); etc. As the result of this research the author has concluded that bribe-takers' behaviour is determined by such psychological constructs as the desire for power, fear, envy, mental deflections, mania, feeling of exclusion, the need for extreme, oppressed creativity.
\end{abstract}

Key words: bribe-takers; bribery; motives; motivation.

\section{Introduction}

Motivation represents the reasons for people's actions, desires, and needs, what causes a person to want to repeat behaviour and vice versa [1].

Studying of bribe-takers' motivation permits to define causes which determine the illegitimate behaviour of bribe-takers and permits to develop mechanisms for more efficient prevention of bribe taking. In order to ensure more efficient fighting with corruption, it is of vital importance to determine what urges an official to become a bribe-taker. Notwithstanding the importance of the problem, this sector still presents lack of qualitytargeted studies. Nowadays there is still no scientifically based psychological conception for researching the bribe-taking problem.

In psychology, as opposed to law, the term "motive" is used in various meanings (for instance, instincts, ideals, needs, emotions, etc.).

The formal constituent elements of bribe taking determine also its subjective side - it is a deliberate offence characterized by a direct intent: a state official acknowledges the harm of their action - bribe taking - and performs it deliberately [2].

Yet, when returning to the issue of distinguishing bribe taking and using an official position in bad faith for purposes of acquiring property that is afforded by a state official, 
unfortunately it must be stated that this issue has not been duly addressed in the theory of criminal law, only a reference can be found that, from the subjective point of view, the crime envisaged in Article 320 of the Criminal Law may be committed only with direct intent [3] and that, when regarding motives of bribe taking, it is of no importance whether a state official takes a bribe with the intention to acquire wealth or due to any other motive [4].

The motive of a criminal offence is the inner encouragement, drive, propensity of a person that directs the will of the guilty party towards a criminal offence.

Within the frames of the article, the author understands the term "motive" as inner force related to person's needs and that motivates this particular person to perform definite actions or, in particular cases, ensures her failure to act.

The article is structured on the basis of Maslow's hierarchy of needs [5]: 1) Physiological Needs; 2) Security Needs; 3) "Belongingness" Needs; 4) Esteem Needs; 5) Self-Actualization Needs; 6) Self-transcendence Needs. Maslow's theory suggests that the most basic level of needs must be met before the individual will strongly desire (or focus motivation upon) the secondary or higher level needs [6].

\section{Materials and methods}

The methods of the present research were: literature review, statistical data, discourse analysis and teleological reduction.

\section{Results}

\subsection{Accepting bribes as physiological needs}

Physiological needs are the physical requirements for human survival. Air, water, and food are metabolic requirements for survival in all animals, including humans. Clothing and shelter provide necessary protection from the elements.

Trubnikov, a specialist in philosophical anthropology, has noted that all person's thoughts and actions are aimed at defeating death. At first, a person wishes to delay death by satisfying their physiological needs (firewood, food, clothes), but, having understood that the physical life is passing, a person tries to extend it by using more durable forms, such as literature, art, etc. [7].

According to Carl Jung, the will to live is the most important motivator of a person's behaviour. Also Ernest Bekker believed that the main driver of a person's actions is fear of death [8, 9]. This opinion relatively coincides with Schopenhauer's thoughts Schopenhauer puts a central emphasis on will and in particular has a concept of the "will to live".

As one of examples when bribes are taken in order to ensure physical survival (ensure for oneself the minimal level of food, dwelling, etc.) it is possible to mention the lower civil servants of the Russian Empire in the late $19^{\text {th }}$ century.

On the basis of that-time sources, professor Golosenko concludes that a part of the Russian civil servants had salaries insufficient for surviving in the late 19th and early 20th century [10].

Namely, N. Rubakin's study regarding income of Russian civil servants in the late 19th century proves that there existed the so-called "slaves of state service" - officials with salary of only 7 roubles per month. At the same time price for food at that period of time was quite high - for instance, 10 eggs cost round 40 kopecks, but unsalted butter 75 kopecks for 410 grams [11]. 
According to the research, conducted by N. Benediktov, regarding dwelling issue, the average civil servants quite often rented damp, dark rooms with no utilities, i.e. premises that were poorly suited for living due to hygienic conditions, due to the lack of money [12].

It is quite difficult to find such examples in the 21 st century. Thus it must be concluded that nowadays this motive of bribe taking cannot be regarded as highly relevant.

\subsection{Accepting bribes as safety needs}

Once a person's physical safety needs are relatively satisfied, their safety needs take precedence and dominate behaviour. Safety and Security needs include: personal security, financial security, health and well-being, safety net against accidents/illness and their adverse impacts.

As it is noted by Erich Fromm, a philosopher, psychologist and sociologist, in society where the main goal is to possess it seems that exactly possessing is the point of existence and a person per se is nil if she does not own anything.

In Fromms' view, neither possession, nor power, nor sensuous satisfaction, can fulfil man's desire for meaning in his life; he remains in all this separate from the whole, hence unhappy. Only in being productively active can man make sense of his life, and while he thus enjoys life, he is not greedily holding on to it. He has given up the greed for having, and is fulfilled by being; he is filled because he is empty; he is much, because he has little $[13,14]$.

Like Edward Lee Thorndike ("we study animal behaviour, not animal consciousness, for the ultimate purpose of controlling behaviour") [15], John Broadus Watson put the emphasis on external behaviour of people and their reactions on given situations, rather than the internal, mental state of those people. Watson pushed for psychology to no longer be considered the science of the "mind". Instead, he stated that psychology should focus on the "behaviour" of the individual, not their consciousness [16].

Nevertheless, in Rogers' view the human being as: "capable of evaluating the outer and inner situation, understanding herself in its context, making constructive choices as to the next steps in life, and acting on those choices" [17, 18].

This short philosophical review makes to think whether a bribe-taker may achieve the desired when looking for safety. The following part of the article will present references to the fact that large sums of money provide for feeling of safety, yet this safety is fictitious.

\subsection{The will to power}

When examining criminal cases related to bribe taking, quite often it is possible to state that officials obtain remarkably huge sums of money in their possession as the result of criminal activities [19-21].

Those sums considerably exceed personal needs. During search it can be seen that in some cases the huge bribes are not even spent, but are kept in cash [22].

Certainly it is difficult to spend the illegally acquired means so that it remains unnoticed, yet any bribe-taker can acknowledge this beforehand. However, notwithstanding the saved amount of the illegally obtained money, officials usually continue to take bribes till the moment when criminal proceedings are commenced against them. What are the causes of such an ill-considered action? What can money give that is not used (or just a small part of which is spent)? If money in this aspect is not intended for spending, then what function does it perform?

We also need to pay attention to such an aspect as sense of power in addition to the first element that we have examined before (sense of safety). In consumer society only money 
gives weight and is a measure of achievements. The preserved money means potential opportunities. In this way the money permits to feel strong and powerful.

In order to better understand this phenomenon, let us pay attention to what happens in wild nature. Every animal occupies a particular place in its pack - a rank that they fight for among themselves. As the result hierarchy is formed that shows the social standing of animals. For example, dominance in wolves typically is determined through strength and skill [23]. However, in modern human society the status is defined by money (money is the potential opportunity to gain power and influence).

Friedrich Nietzsche in his work "Beyond Good and Evil" [24] equates a concept "Will to power" (German: der Wille zur Macht) to life per se: "Even the body within which individuals treat each other as equals, as suggested before - and this happens in every healthy aristocracy - if it is a living and not a dying body, has to do to other bodies what the individuals within it refrain from doing to each other: it will have to be an incarnate will to power, it will strive to grow, spread, seize, become predominant - not from any morality or immorality but because it is living and because life simply is will to power."

On the one hand, Friedrich Nietzsche attributed the concept "will to power" to living beings as such, without distinguishing activity of these living beings (humans among them). If the power is mostly related to brutal force in wild nature, then in the present-day society the rights and possibility to rule, to determine and subject (i.e. power) to a great extent depends also on such constructs as functions and authorities.

Functions and authorities regarding administration, supervision and decision-taking of a public resource considerably exceed possibilities of an average citizen that creates real risk of corruption per se. In addition, acquisition of a status of a public official is a quite easy way to obtain power. At the same time it can be concluded that quite often it is not enough to receive a position in order to feel complete sense of power.

On the other hand, the feeling of power in itself affects the person's thinking process (see: Lammers - power, like alcohol, brings about a kind of moral Myopia - provokes behaviour that is described as a hyper-self-confident or hyper-assertive) [25].

It can be concluded from the aforementioned that a person who has received a position of an official with the aim to obtain sense of power (in order to mitigate the inferiority complex developed during childhood) will engage in bribe taking with high probability. It is also confirmed by conclusions made by Alfred Adler, who states: "The Ruling or Dominant type strive for power and are willing to manipulate situations and people, anything to get their way. People of this type are also prone to anti-social behaviour." [26].

In this context, the Adler's interpretation seems interesting: to convert feelings of inferiority to superiority [27]. If the corrective factors were disregarded and the individual overcompensated, then an inferiority complex would occur, fostering the danger of the individual becoming egocentric, power-hungry and aggressive or worse [28].

When regarding the phenomenon of "will to power" in the frames of bribe taking, we need to be very careful. Under no circumstances can we automatically relate the fact of power acquisition with willingness to take bribes. We should pay attention not to the fact that a person wishes to obtain a status of a public official, but to the motivation of this particular person, for instance, a person who has received the position not in order to acquire the sense of power, but for other motives (to improve public conditions, to help the working poor, etc.) will doubtfully engage in corruption.

\subsection{Accepting bribes as "Belongingness" needs}

According to Maslow, humans need to feel a sense of belonging and acceptance among their social groups, regardless whether these groups are large or small. 
This need for belonging may overcome the physiological and security needs, depending on the strength of the peer pressure. It is well-known that in countries where social institutions are efficient, bribe taking becomes a marginal phenomenon [29]. Nevertheless in countries, where bribe taking can be regarded as an admissible phenomenon, one of the motives to take a bribe is fear of breaking "rules of the game", fear of becoming a "black sheep".

In a world of hunchbacks, a fine figure becomes a monstrosity [30] and it is of extreme difficulty for an official to act honestly when starting one's career in an institution where bribe taking is accepted as a standard.

On the basis of conclusions of the social identity theory and self-categorization theory, it can be concluded that adaptation in a collective body envisages acknowledgment and acceptance of standards effective in that particular collective body. In case the conflict between an individual's core values and collective body's core values is not eliminated it leads to disintegration - isolation of an individual and exclusion from a particular group.

Thus, on the one hand, an official is influenced by actual conditions (the bribe taking subculture existing in the society). On the other hand, it is convenient for a person to agree with standards existing in a society and a collective body as this is the direction where "belongingness". This desire is so universal that the need to belong is found across all cultures and different types of people [31].

Belongingness to a group enables a person to feel their value [32]. It is of particular significance in a work place.

Employees want to fit in at work as much as students want to fit in at school. They seek the approval of their leaders, bosses, and other employees in order to be accepted. A sense of belongingness increases a person's willingness to assist others in the group by the group rules [33].

Sometimes this sense of belongingness is achieved regardless of inconvenience, awaiting the very individual: "With the social animal controlled by herd instinct, it is not the actual deed which is instinctively done, but the order to do it which is instinctively obeyed. The deed, being ordained from without, may actually be unpleasant, and so be resisted from the individual side, and yet be forced instinctively into execution" [34].

Thus in countries where bribe taking is a common phenomenon, belongingness prepares good soil for corruption to take roots. While in countries, where corruption is actually condemnable, belongingness helps to ensure efficient fight against bribe taking. This phenomenon is reinforced by fear of standing out, the herd instinct ("power of crowds") [35].

Although Jean William Fritz Piaget believed that a person forms her own moral views, even when a child [36]. Piaget believed that children made moral judgments based on their own observations of the world.), yet in this aspect we have to agree with the thesis expressed by Gustave Le Bon - " ... the individualities in the crowd who might possess a personality sufficiently strong to resist the suggestion are too few in number to struggle against the current. /.../ the individual in a crowd differs essentially from himself. Even before he has entirely lost his independence, his ideas and feelings have undergone a transformation, and the transformation is so profound as to change the miser into a spendthrift, the sceptic into a believer, the honest man into a criminal, and the coward into a hero" [35].

Erik Homburger Erikson (1902-1994) showed how personality development in certain key individuals can induce widespread cultural changes.

Perhaps more intriguing, and troubling, is that some individuals' personalities and moral dispositions may change when they become part of a group. "Social identity theory" suggests that a person can think an act is immoral before becoming a part of the group, and then their personality changes to conform to the predominant identity of the group. Research suggests that this social identity theory may indeed explain why corruption can persist in a system long after the original corrupt actors leave [37].

In countries with ancient corruptive traditions a person is often regarded as a biological construct of little significance, as an insignificant part of a state mechanism. One of the 
most real possibilities to improve the situation could be rise of a value of each individual personality in society.

\subsection{Accepting bribes as esteem needs}

All humans have a need to feel respected; this includes the need to have self-esteem and self-respect. Maslow noted two versions of esteem needs: a "lower" version and a "higher" version. The "lower" version of esteem is the need for respect from others. This may include a need for status, recognition, fame, prestige, and attention. The "higher" version manifests itself as the need for self-respect. For example, the person may have a need for strength, competence, mastery, self-confidence, independence, and freedom.

Striving for esteem in the modern world is closely related to the perception of society regarding what really is to be respected. In the modern consumer society it is usually money, power, and success.

Alfred Adler [38] noted that one of the most important phenomena in the human nature is an individual's drive for superiority and success.

Individuals who have a high external locus of control tend to have higher levels of psychological and physical problems. These people are also more vulnerable to external influences $[39,40]$.

According to William Isaac Thomas (Thomas theorem), if men define situations as real, they are real in their consequences [41].

When a person feels underestimated, unsafe or inferior, they will always want to obtain higher position in order to receive compensation and sense of content in that way. Often sense of lack of compensation and fear of not achieving the desired goal cause additional problems. Namely, in case the desire for superiority becomes extremely strongly expressed, it could cause a sense of envy in parallel.

As Helmut Schoeck puts it [42], a person, who has a passive envy of something, can very easily turn into an aggressive criminal (in our case - a bribe-taker).

\subsection{Accepting bribes as self-actualization}

This level of need refers to what person's full potential is and the realization of that potential. Individuals may perceive or focus on this need very specifically. Maslow believed that to understand this level of need, the person must not only achieve the previous needs, but master them.

According to Maslow, a personality who self-actualizes lives fuller life and with greater sense, than an average individual who is mainly motivated by satisfaction of their needs [5]. When characterising people regarding self-actualization, Maslow indicates the following peculiarities of such people: more effective perception of reality and more comfortable relationship with her; adoption (self, others, and nature); spontaneity, simplicity and naturalness; the centrality of the task; some thedi-lennosti and need for privacy, autonomy, independence from the culture and environment; permanent freshness assessment; mysticism and the experience of higher States; the sense of belonging, of being one with the other; the deeper interpersonal relations; democratic character structure; differentiating the means and the objectives of good and evil; philosophical, non-hostile sense of humour; savakta-lysed creativity; the resistance of acculturation.

Self-actualization is a difficult and painful process involving continuous challenges to one's capabilities [43] wrote, "It involves the courage to be. It means launching oneself fully into the stream of life."

Rogers offered [44] five specific characteristics of the fully functioning person: Openness to Experience; Existential Living; A Trust in One's Own Organism; A Sense of 
Freedom; Creativity (Creative individuals are not known for conformity or passive adjustment to social rules; due to their lack of defensiveness, they are not concerned with approval from others for their behaviour. The fully functioning person is thought to be more capable of adapting to and surviving drastic life changes due to the creative and spontaneous element).

In the following part of the article we need to answer a question whether these five specific characteristics of the fully functioning person can be attributed also to a bribetaker.

Does the bribe-taker possess openness to experience, existential living, and a sense of freedom? Can the bribe-taker be creative? In other words, can the bribe-taker experience self-actualization?

It must be concluded that self-actualization may be varied, i.e., self-actualization can be expressed not only in forms approved by the society. The humanistic approach [ccc] envisages that the inner harmony is possible when a person is a self-actualizing personality. Nonetheless finding an occupation that is satisfactory for the person should be settled for each person individually. It is not excluded that this harmony is achieved also by individual people who have decided to become bribe-takers.

The Personal Orientation Inventory (POI) by Everett L. Shostrom. According to the POI testing, the level of self-actualization amongst criminals was higher than among college students [45]. In this aspect particular attention should be paid to creativity. Sigmund Freud has searched for pathological causes of a genius; Florian Witold Znaniecki has indicated that a person possesses also the irrational next to the rational [46].

This irrational is to great extent related to creative activity as creative activity differs from a natural process exactly in a way that it provides for a new, previously non-existing element [46]. The aforementioned confirms that both creativity and crime may have common features. For instance, just like a criminal offence, also creativity is closely related to violation of standards (perceptions) existing in society, both creativity and crime are not possible without breaking the previously set limit, without reaching another dimension. Both a criminal and a creative person destroy barriers with their activity.

It is not possible to assert that any criminal is more creative than an average person, yet it is significant that, according to the results of Den Arieli's research, greater success in manipulations is achieved by creative personalities with non-standard approach to problem solving and with developed imagination [47].

In this relation it is of significance to pay attention to the assumption that bribe taking may also be the creative potential used in a wrong (destructive) way.

The role of a bribe-taker, especially in the high level bribe taking, requires a person to possess particular characteristics. These people are usually better adapted to changes, they possess plasticity, adaptability. Typical bribe-takers feel the state of affairs and perfectly understand hierarchy within the system, understand nuances of social interaction, are socially active and communicative.

Gilinsky [48], a criminologist, believes that a person's activity can be manifested both in a positive (creative activities) and a negative way (crimes). In this plane, if an official's creativity is artificially suppressed, bribe taking can be interpreted as a protest against routine, social pressure, and lack of creativity.

\subsection{Self-transcendence}

In his later years, Maslow explored a further dimension of needs, while criticizing his own vision on self-actualization [49]. The self only finds its actualization in giving itself to some higher goal outside oneself, in altruism and spirituality [50-52]. 
Self-transcendence as assessed in the Temperament and Character Inventory originally had three subscales $[53,54]$.

A study relating the Temperament and Character Inventory to the Five factor model personality traits (1. Self-forgetful vs. self-conscious experience; 2. Transpersonal identification vs. self-isolation; 3. Spiritual acceptance vs. rational materialism; 4. Enlightened vs. Objective; 5. Idealistic vs. Practical) found that self-transcendence was most strongly related to openness to experience and to a lesser extent extraversion [55].

The level of self-transcendence illustrates which level of Maslow's hierarchy of needs bribe-takers nevertheless do not reach.

\section{Conclusions}

1. When examining the fact of bribe taking, we primarily need to understand that any action is affected by various elements; in addition, all these elements are interrelated. For instance, it would be wrong to indicate that the bribe-taker's motive is greediness as such, without examining causes of appearance of greediness in the personality of the particular bribe-taker. Largely, it is possible to confine oneself to the motive of greediness only in case if a bribe-taker tries to satisfy the primary (physical) needs. Yet, if money serves to satisfy secondary - psychological - needs, we should search for deeper motives of bribe taking.

2. Exaggerated drive for material benefits in the bribe-taker's personality may form under influence of several causes - sublimation of childhood fear and poverty, search for safety, willingness to overcome the sense of weakness, feeling of being unprotected, of being inferior, will for power, for self-actualization, fear of becoming a "black sheep", etc.

3. The bribe-taker's motivation is to great extent not a problem of sociology or economics, but a problem of philosophy and psychology. Bribe taking by itself indicates that a person has problems (unsatisfied needs). Nowadays the issue of physical survival due to lack of financing (according to Maslow - physiological needs) currently is not important for officials. Thus, we need to analyse official's psychological needs. In this aspect it must be concluded that in any case the fact of bribe taking is a proof (confirmation) that the person's life philosophy has failed. If we reduce the Fromm's conclusions to the problem of corruption, then bribe-takers live with a willingness to convert everything surrounding into their property, they want to control. Whereas the real life envisages freedom, independence, autonomy and critical thinking, inherent activity (to use one's potential, talents, to develop, hold an interest, achieve particular goals, and share with others).

4. Accepting bribes as self-actualization is a problem that the society will have to face even more often. If bribe taking takes place on the level of self-actualization, then it is not really possible to talk about an individual's discontent per se. Bribe taking as selfactualization is a deviation that does not comply with social norms.

\section{References}

1. A.J. Ellliot, M. Covington, Approach and Avoidance Motivation, Educational Psychology Review 13, 2 (2001)

2. www.at.gov.lv/files/uploads/files/6_Judikatura/Tiesu.../ AT_petijums_kukulosana.doc (2015)

3. U. Krastiņš, V. Liholaja, A. Niedre, Krimināltiesības. Sevišķā daļa. Trešais papildinātais izdevums. Rīga : Tiesu namu aǵentūra, 766.lpp. (2009) 
4. D. Mežulis, Korupcijas ierobežošanas krimināltiesiskie aspekti. Rīga : Latvijas Vēstnesis, 79. lpp. (2003)

5. A. Maslow, Motivation and Personality, N.Y. (1954)

6. F. Goble, The third force: The psychology of Abraham Maslow. Richmond, CA: Maurice Bassett Publishing, pp. 62 (1970)

7. Н.Н. Трубников, О смысле жизни и смерти, М., С. 84 (1996)

8. E. Becker, The denial of death. N.Y., Free Press (1973)

9. E. Becker, The Birth and Death of Meaning. N.Y., Basic Books (1971)

10. http://www.jourssa.ru/sites/all/files/volumes/1999_3/Gol osenko_1999_3.pdf (1999)

11. Н. А. Рубакин, К статистике русского чиновничества, Спутник Чиновника, №№3,4.; № 4, с. 1-2 (1912)

12. Н. Бенедиктов, Жилищная нужда чиновников, Спутник Чиновника, №4. с. 21 $22(1911)$

13. E. Fromm, Marx's Philosophy of Man (1961)

14. E. Fromm, Man for Himself, Rinehart \& Co., New York (1947)

15. http://www. muskingum. edu/ psych/psycweb/history/ thorndike.htm

16. http://www. newworldencyclopedia.org/entry/John_B. Watson

17. C. Rogers, Carl Rogers on personal power. N.Y., Delacorte Press, p. $\overline{15}$ (1977)

18. An Analysis of Carl Rogers' Theory of Personality by Dagmar Pescitelli. http://pandc.ca/?cat=carl_rogers\&page=rogerian_theory (1996)

19. Head of Russia's anti-corruption agency is found with $\$ 122 \mathrm{~m}$ in CASH in his house. http://www.dailymail.co.uk/news/article-3784186/HeadRussia-s-anti-corruption-agency-122m-CASHhouse.html\#ixzz4V0Kunm9v (2016)

20. 11 Ashmiany Customs Officials' High-Profile Trial Started In Minsk https: / / charter97.org/en/news/2016/11/18/231524/ (2016)

21. Pictured: Inside former Ukraine general prosecutor's luxury home that was "built on corruption". http: / / www.mirror.co.uk/news/world-news / pictured-ukraines-former-general-prosecutor-3181937 (2014)

22. Senior Russian anti-corruption official arrested after police find $\$ 123$ million in cash at his home.

http: //www. independent.co.uk/news/world/europe/seniorrussian-anti-corruption-official-arrested-after-policefind-123-million-in-cash-at-his-home-a7239041.html (2016)

23. Wolves of the World. http: //wolph.onbile.com/packhierarchy

24. F. Nietzsche, Beyond Good and Evil (1886)

25. J. Lammers, A.D. Galinsky, E.H. Gordijn, S. Otten, Power increases social distance, Social Psychological and Personality Science 3, 282-290 (2012)

26. H. H. Mosak, M. Maniacci, A Primer of Adlerian Psychology, 64-65 (1999)

27. A. Adler, The Neurotic Character (1912)

28. A. Adler, Understanding Human Nature, Chapter 11, Aggressive Character Traits (1927)

29. http://ipulsar.net/newsnew-727.html

30. H. de Balzac, La Comedie Humaine (1851)

31. R.F. Baumeister, M.R. Leary, The need to belong: Desire for interpersonal attachments as a fundamental human motivation, Psychological Bulletin 117(3), 497-529 (1995)

32. W. McDougall, An Introduction to Social Psychology, Boston, Luce (1912) 
33. D.N. Den Hartog, A.B. de Hoogh, A.E. Keegan, The interactive effects of belongingness and charisma on helping and compliance, Journal of Applied Psychology 92(4), 1131-1139 (2007)

34. W. Trotter, Instincts of the Herd in Peace and War, T. F. Unwin Ltd, London. p. 48 (1916)

35. G. le Bon, The Crowd: A Study of the Popular Mind (1895)

36. https://en.wikipedia.org/wiki/Jean_Piaget

37. E.H. Erikson, http://www .encyclopedia.com/people/medicine/psychologyand-psychiatry-biographies/erik-erikson

38. A. Adler, The Education of Children. Gateway Editions, Ltd South Bend Indiana (1978)

39. H.M. Lefcourt, Locus of Control: Current Trends in Theory and Research. NJ: Lawrence Erlbaum Associates (1976)

40. R.E. Smith, Effects of coping skills training on generalized self-efficacy and locus of control, Journal of Personality and Social Psychology 56(2), 228-33 (1989)

41. W.I. Thomas, D.S. Thomas, The child in America: Behavior problems and programs. New York, Knopf, 571-572 (1928)

42. H. Schoeck, Envy: a theory of social behaviour, Liberty Fund, Indianapolis (1969)

43. http://www.texcpe.com/html/pdf/fl/FLHP.pdf

44. C. Rogers, On Becoming a Person: A Therapist's View of Personality. Boston, Houghton Mifflin (1961)

45. E.L. Shostrom, Man, the manipulator: The inner journey from manipulation to actualization. Nashville, TN: Abingdon (1967)

46. F. Znaniecki, Wstęp do socjologii. Poznan 116 (1922)

47. http://www. learningfirst.org/predictably-irrationalconversation-best-selling-author-dan-ariely

48. Я. И. Гилинский, Н. А. Исаев, Ю. А. Клейберг и др.,Творчество как позитивная девиантность. Российский государственный педагогический университет им.

А. И. Герцена, Санкт-Петербургский Центр девиантологии, СПб., Алеф-Пресс, 279 c. (2015)

49. A.H. Maslow, Critique of self-actualization theory, in: E. Hoffman (Ed.), Future visions: The unpublished papers of Abraham Maslow (Thousand Oaks, CA: Sage), pp. 26-32 (1996)

50. A.H. Maslow, The farther reaches of human nature, Journal of Transpersonal Psychology 1, 1-9 (1969)

51. A.H. Maslow, The farther reaches of human nature, New York: The Viking Press (1971)

52. M.E. Koltko-Rivera, Rediscovering the Later Version of Maslow's Hierarchy of Needs: Self-Transcendence and Opportunities for Theory, Research, and Unification, Review of General Psychology 10(4), 302-317 (2006)

53. C.R. Cloninger, DM. Svrakic, T.R. Przybeck, A psychobiological model of temperament and character, Archives of General Psychiatry 50(12), 975-90 (1993)

54. D.A. MacDonald, D. Holland, Examination of the psychometric properties of the temperament and character inventory self-transcendence dimension. Personality and Individual Differences 32(6), 1013-1027 (2002)

55. F. de Fruyt, L. Van De Wiele, C. Van Heeringen, Cloninger's Psychobiological Model of Temperament and Character and the Five-Factor Model of Personality. Personality and Individual Differences 29(3), 441-452 (2000) 